\title{
Derivative Analysis of Value Added to Stock Returns at Jakarta Islamic Index
}

\author{
Fuad Hasyim ${ }^{1}$, Resyta Aulia Ardityasari² \\ IAIN Surakarta ${ }^{1}$, IAIN Surakarta ${ }^{2}$ \\ hasyimfuad19@gmail.com ${ }^{1}$
}

\begin{abstract}
This study aims to examine the effect of value added derivative such as economic value added (EVA), market value added (MVA) and refined economic value added (REVA) on stock return with stock price as an intervening variable. The object of this study are all Islamic stocks listed in the Jakarta Islamic Index (JII) in the period 2014-2019. This study using purposive sampling method and obtained by 11 companies. Data processing using panel regression with common, fixed and random modelling approach. The results show that economic value added (EVA) has no effect either on stock prices or stock returns, market value added (MVA) affects the stock price and stock return, while refined economic value added (REVA) has no effect on both. Then, stock prices are only able to mediate the effect of market value added (MVA) on stock return.
\end{abstract}

Keyword: EVA, MVA, REVA, stock price, stock return, panel data

\begin{abstract}
Abstrak
Penelitian ini bertujuan untuk menguji pengaruh economic value added (EVA), market value added (MVA) dan refined economic value added (REVA) terhadap return saham dengan harga saham sebagai variabel intervening. Objek penelitian ini adalah seluruh saham syariah yang terdaftar di Jakarta Islamic Index (JII) periode 20142019. Penelitian ini menggunakan metode purposive sampling dan diperoleh 11 perusahaan. Pengolahan data menggunakan regresi panel dengan pendekatan common, fixed dan random modeling. Hasil penelitian menunjukkan bahwa economic value added (EVA) tidak berpengaruh baik terhadap harga saham maupun return saham, market value added (MVA) berpengaruh terhadap harga saham dan return saham, sedangkan refined economic value added (REVA) tidak berpengaruh pada keduanya. Kemudian harga saham hanya mampu memediasi pengaruh market value added (MVA) terhadap return saham.
\end{abstract}

Kata Kunci: EVA, MVA, REVA, harga saham, return saham, data panel

\section{PENDAHULUAN}

The capital market is a source of funds for any company that requires long-term funds. As time goes by, companies that trade in stocks are increasing. The development of the Islamic capital market has progressed so that it has created an intention for investors to invest in the Islamic capital market. Investing in the capital market is a recommended muamalah activity, and is an active form of sharia economics (Haanurat, 2013). Inarno Djajadi (President Director of IDX) said that the number of sharia investors in the capital market has increased significantly from 2014. The last five years the number of Islamic investors in the capital market has increased significantly, 
by $1.64 \%$ from 2,075 investors at the end of 2014 to 47,165 investors as of February 2019. The level of activeness of Islamic investors reached $40 \%$ (liputan 6.com).

A company should be considered successful only if it yields the project is better than the returns that investors can expect on investment in the capital market (Bodie et al., 2006). Investors' assessment of a company's shares is by paying attention to the performance of the company that issued the shares. Therefore, stock returns are very important for companies because they are used as a measure of the performance of a company so that in order for the stock portfolio to be invested to increase, the company must try to maintain and improve its performance which can affect stock returns (Haanurat, 2013). If the financial performance has a good performance, then the purchasing power is likely to increase. The high purchasing power of shares indicates high demand and has an impact on stock prices.

Investors must choose wisely a good company to get a return, one way is by looking at its financial performance. There are several other financial performance measurement tools that ignore the cost of capital, so that they are unable to reveal how much the company creates value for its owners. According to Sunardi (2010) there are several weaknesses of accounting profit measurement tools, including: not paying attention to risk, ignoring the cost of capital, only paying attention to the results (company profits). Based on the above limitations, a value added based financial performance measurement tool is proposed as an alternative to forecasting stock prices. By using the added value concept, it is hoped that it can present realistic measurement results of financial performance and support the presentation of financial reports such as: Economic Value Added (EVA), Market Value Added (MVA) and Refined Economic Value Added (REVA).

Economic Value Added (EVA) measures the added value produced by a company by reducing the cost of capital that arises as a result of investments made (Andrias \& Margasari, 2017). Steward and Stern from Stern Stewart are the figures who first developed EVA. They are a Consulting firm in New York, USA. A good company's financial performance might be able to attract large numbers of investors so that its share price can increase (Syahputra, 2018).

Economic Value Added (EVA) is able to calculate the actual economic profit or true economic profit of a company in a certain year and is very different when compared to accounting profit. EVA reflects the residual income that remains after deducting all costs of capital including share capital. EVA provides a better measurement of the added value that the company provides to shareholders (Sartono, 2010).In addition to the use of Economic Value Added, companies also use Market Value Added to view the company's financial performance with the aim of maximizing the prosperity of shareholders (Sartono, 2010). In addition, you can also use the concept of Refined Economic Value Added. The concept of Refined Economic Value Added (REVA) is the concept of Economic Value Added (EVA) which was 
refined by Bacidore. According to Lestari \&Oktaria (2019), REVA uses calculation components such as EVA, but what distinguishes it is in treating capital. EVA uses the economic book value (economic book value) while REVA uses the market value of the firm, because it is considered more reflective of shareholder wealth than economic book value. In REVA, operating profit after tax (NOPAT) is reduced by the cost of capital from the market value of the capital invested.

There are several studies that compare the concepts of EVA and REVA, such as research conducted by Bacidore et al. (1997) which states that performance measurement using REVA is better than EVA. However, it is different from the research of Ferguson \& Leistikow (1998) which states that theoretically REVA is still inferior to EVA as a performance measurement tool that is closely related to creating value for shareholders. The results of other research, conducted by Rahadjeng (2019), on the analysis of the use of measuring tools for EVA, REVA, MVA and FVA in measuring financial performance, show that MVA provides greater positive added value than the other three added values. Research by Bosra et. al. (2013) also concluded that based on the F-Limer and Hausman test, almost all industries showed a better relationship between EVA and stock returns than REVA. However, based on the results of the t-statistic test, the relationship between REVA and stock returns is better and significant compared to EVA. The reasons for using these three measuring instruments are simultaneously used in this study to re-examine the consistency in measuring company performance in terms of stock prices and which stock returns are better. The three measuring instruments are expected to reflect how well the company's ability to manage the company's sources of funds and measure the company's success in providing added value to stock prices in the Indonesian capital market, especially for its owners.

In addition, there are still inconsistencies in research results previous research results such as Nugroho (2018), show that EVA, MVA and REVA have a positive and significant effect on stock prices of manufacturing companies listed on the IDX. These results are in line with research conducted by Sonia et al. (2014), which concluded that EVA and MVA have an effect on stock prices. Meanwhile, different results are shown by research by Agnatia \& Amalia (2018), Rosmawati (2018) and (Mardiyanto, 2013), which conclude that EVA has no effect on stock prices. Research conducted by Febriyanto \& Rizkiyanto (2015), Silaban (2013) concluded that REVA has no effect on stock prices.

Furthermore, Nugroho's research (2018) shows that EVA, MVA and REVA have an effect on stock returns in manufacturing companies listed on the IDX. This result is in line with the research of (Alexander \& Destriana (2013), showing that EVA and MVA have an effect on stock returns. Meanwhile, research results that are not in line are shown by Kusuma \& Topowijono (2018) research, which concludes that EVA has no significant effect on stock returns. In addition, Cahyadi \& Darmawan, (2016)research 
concluded that MVA has no effect on stock returns. As well as research conducted by Lestari \& Oktaria (2019), it is concluded that REVA has no effect on stock returns.

In 2019, OSO Sekuritas analyst Sukarno Alatas assessed that the shares of JII residents benefited from the negative sentiment that hit the IHSG. JII is considered not too affected by this sentiment. However, these stocks benefit more from the price side (kontan.co.id). Sentiment itself means the optimistic or pessimistic attitude of consumers and producers related to the economy which is an important determinant of economic performance (Bodie et al., 2006). This is what makes researchers interested in making companies listed in the Jakarta Islamic Index (JII) an object to be researched.

\section{LITERATURE REVIEW}

\section{Signaling Theory}

This theory states that good financial reports published by a company can be used as a signal or a sign that the company is operating well. Financial reports that contain information about the company are a signal for investors in making investment decisions. If the report gives a positive value, it is expected that the market will react. Market reactions are indicated by changes in stock trading volume caused by investors using existing information for analysis resulting in changes in volume in stock trading (Sunardi, 2010).

An investor will only invest if the company they think can provide added value for capital is greater than if they invested elsewhere. For this reason, companies that are able to create positive returns reflect more and more that the company is able to manage their assets well. The company is expected to react in the form of increased share purchasing power, followed by changes in share prices. Market reactions are indicated by changes in share prices at the time the information is announced and all market participants receive the information and interpret and analyze the information as good news or bad news. If the information is considered as good news, there will be an increase in demand for shares so that stock returns will increase.

\section{Economic Value Added (EVA)}

The EVA method was first developed by Stewart and Stern, a financial analyst from the company Stern Stewart \& Co in 1993. According to Mardiyanto (2013) this model departs from the concept of the cost of capital, which is reducing profits with the cost of capital, where expenses This cost of capital reflects the level of compensation or return that investors expect. The results of the calculation of positive EVA values reflect a higher rate of return than the cost of capital. According to Nugroho (2018) Economic Value Added (EVA) is economic value added after tax operating profit is reduced by the amount of capital cost structure used by the company. The concept of the cost of capital is a very important concept in this approach, because EVA itself departs from the calculation of the cost of capital. The company's cost of 
capital can be defined as the rate of return that must be obtained in order to meet the combined level of profits expected by the company's investors.

The EVA concept also describes three steps that can be used to view company performance, namely:

1. If EVA>0, it means that the company has created economic added value for the company.

2. If $E V A=0$, then it shows the position of BEP (break-even) in the company where all profits are used to pay obligations to investors.

3. If EVA $<0$, it means that the company does not generate added value for the company, because profits cannot meet investor expectations.

If a company has an economic added value that is greater than zero during its operations, this will usually be followed by an increase in the company's share price. If it is equal to zero, then the company is in a breakeven state, meaning that the expected return will be the same as the previous return. If it is less than zero, then the company fails to meet the expectations of investors and is usually followed by a decline in the company's share price. This is supported by research conducted by Nugroho (2018), Sonia et al. (2014) which states that Economic Value Added affects stock prices.

$H_{1}$ : Economic Value Added affects to Stock Price.

A positive EVA indicates a rate of return that exceeds the cost of capital in the company. So that the company can fulfill the company's obligations and investors' expectations can be fulfilled. This is supported previous research which state that Economic Value Added affects stock returns (Alexander \& Destriana, 2013; Cahyadi \& Darmawan, 2016; Nugroho, 2018).

$H_{2}$ : Economic Value Added affects the Stock Return.

\section{Market Value Added (MVA)}

Young \& O'Byrne (2001) explain that MVA is the difference between the market share price and the total invested capital or the value of the company's equity. The company's goal, which was originally to seek as much profit as possible, has now shifted to maximizing the prosperity of shareholders. This is because if you maximize the shareholder's prosperity, investors will invest in the company. Stewart defines MVA, which is a cumulative measure of financial performance which shows how much value added to the capital invested by investors while the company was founded or clearly MVA is the difference between market value of equity and book value of equity.

Indicators used to measure Market Value Added (MVA) according to Young and Young \& O'Byrne (2001), namely:

1. If the Market Value Added (MVA) $>0$ has a positive value, the company has succeeded in increasing the value of capital invested by the funder.

2. If the Market Value Added (MVA) $<0$, is negative, the company has not succeeded in increasing the value of capital invested by the funder. 
MVA which has a positive value indicates that the stock is valued at greater than the book value per share by investors, so it will attract investors to invest in the company. A bigger MVA shows that the added value for investors is also greater, so that it is followed by an increase in share prices. This is supported by research conducted by Rahayu \& Dana (2016), Mardiyanto (2013) which states that Market Value Added has a positive and significant effect on stock prices.

H3: Market Value Added affects to Stock Price

Companies that originally aimed to get as much profit as possible have now shifted to prospering shareholders through a rate of return, so that investors will be more interested in investing. MVA measures the added value of the invested capital by investors. A positive MVA shows that the manager has succeeded in creating wealth for shareholders. This is supported by research previous which state that Market Value Added affects stock returns (Alexander \& Destriana, 2013; Kusuma \& Topowijono, 2018; Nugroho, 2018). $H_{4}$ : Market Value Added affects the Stock Return.

\section{Refined Economic Value Aded (REVA)}

Refined Economic Value Added is an EVA measuring instrument model, which is enhanced by differentiating in treating capital. In EVA using economic book value (economic book value), while REVA uses the market value of the firm because it is considered more reflective of shareholder wealth than economic book value (Bacidore et al., 1997).

The interpretation of the REVA measurement results can be explained as follows:

1. If REVA $>0$, this indicates that there has been a process of economic added value for the company or there is additional economic value after the company has paid all obligations to funders, both creditors and shareholders in the capital market.

2. If REVA $=0$, this indicates that there is no added value or economic reduction process because the profit has been used up to pay obligations to funders, both creditors and shareholders in the capital market.

3. If REVA $<0$, this indicates that there is no economic value added process for the company or the company is unable to pay its obligations to funders, both creditors and shareholders in the capital market.

As with EVA, REVA which is positive shows that the company has the ability to fulfill company obligations and provide benefits to investors through dividend distribution which causes an increase in stock prices in the market. This is supported by research conducted by Nugroho (2018) which states that Refined Economic Value Added affects stock prices.

H5: Refined Economic Value Added affects to Stock Price

The use of measurement using REVA will encourage managers to think and act like shareholders, namely to maximize the rate of return and cost of capital and opportunity costs so that the company value can increase continuously. This is supported by research by Nugroho (2018) which states that Refined Economic Value Added affects stock returns. 
Derivative Analysis of Value Added to Stock Returns at Jakarta Islamic Index

H6: Market Value Added affects the Stock Return.

\section{METHODOLOGY}

The population taken in the study were all 30 companies listed on the Jakarta Islamic Index (JII). The research sample was selected by purposive sampling method, namely the sampling technique with certain considerations (Sugiyono, 2017b).

1. Companies Listed in the Jakarta Islamic Index (JII). 30

2. Companies that are consistent in JII during the 2014-2019 period

3. Companies that do not have complete financial statement data during the study period.

The sample is part of the number and characteristics of the population (Sugiyono, 2017b). The sample used in this study amounted to 11 companies that were consistent in JII during the research period, namely 6 years, so that the research data amounted to 66 observations.

Table 1. Research Sample

\begin{tabular}{lll}
\hline No & \multicolumn{1}{c}{ Code } & \multicolumn{1}{c}{ Companies Name } \\
\hline 1 & ADRO & PT. Adaro Energy Tbk \\
2 & AKRA & PT. AKR Corporindo Tbk \\
3 & ASII & PT. Astra Internasional Tbk \\
4 & BSDE & PT. Bumi Serpong Damai Tbk \\
5 & ICBP & PT. Indofood \\
6 & INDF & PT. Indofood Sukses Makmur Tbk \\
7 & KLBF & PT. Kalbe Farma Tbk \\
8 & SMGR & PT. Semen Indonesia Tbk \\
9 & UNTR & PT. United Tractors Tbk \\
10 & UNVR & PT. Unilever Indonesia Tbk \\
11 & WIKA & PT. Wijaya Karya Tbk \\
\hline
\end{tabular}

Source: www.idx.com dan www.sahamok.com

The data used in this research is panel data. Panel data is data consisting of cross section and time series data. According to Widarjono (2013), to estimate model parameters with panel data, three techniques are described, namely:

1. Common effect model. This technique is the simplest technique for estimating panel data, by combining cross section and time series data as a single unit regardless of time and individual differences. The approach used in this model is the Ordinary Least Square (OLS) method.

2. Fixed effect model. This technique estimates the panel data using dummy variables to capture the difference in interceptions. This model assumes that the interceptions between companies are different while the slope remains the same between companies to detect differences. The approach used in this model uses the Least Square Dummy Variable (LSDV) method.

3. Random effect model. This technique uses the Generalized Least Square (GLS) method to estimate panel data where the disturbance variables may 
be interrelated over time and between individuals. The differences between individuals and between times are accommodated through errors.

Figure 1. Outline Modelling Research

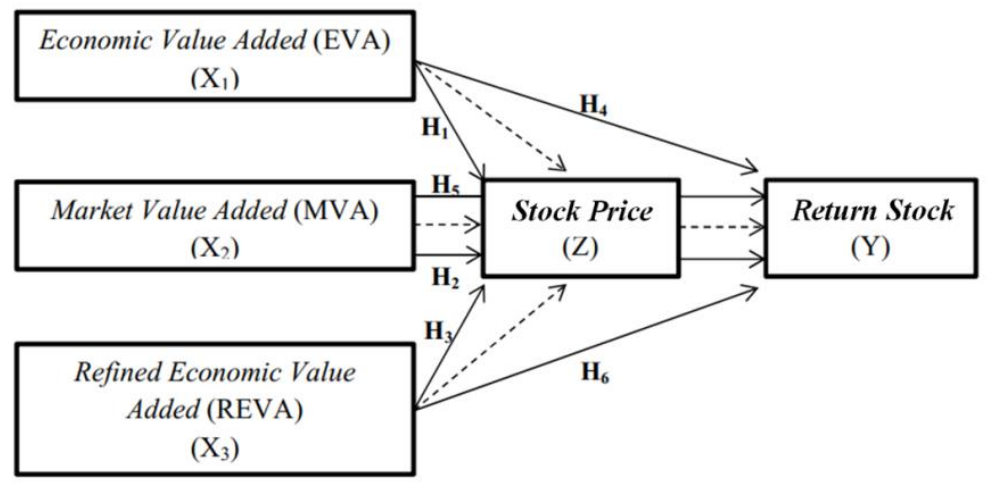

This study uses linear regression with mediating variables. Mediating or intervening variables are intervening variables that lie between the independent and dependent variables, so that the independent variable does not directly affect the change or emergence of the dependent variable (Sugiyono, 2017a). Panel data regression analysis using mediating variables can be carried out using the Causal Step method developed by Baron \& Kenny (1986)and the Product of Coefficient (Sobel Test) developed by Sobel. In this study using the Causal Step method with the research model in Figure 1 above, three regression equations will be obtained as follows:

$$
\begin{array}{ll}
\text { ReturnStock } & =\alpha+\beta 1 E V A_{i, t}+\beta 2 M V A_{i, t}+\beta 3 R E V A_{i, t}+\varepsilon \\
\text { Stock Price } & =\alpha+\beta 1 E V A_{i, t}+\beta 2 M V A_{i, t}+\beta 3 R V A_{i, t}+\varepsilon \\
\text { ReturnStock } & =\alpha+\beta 1 E V A_{i, t}+\beta 2 M V A_{i, t}+\beta 3 R E A_{i, t}+\beta \text { Stock Price }_{i, t}+\varepsilon
\end{array}
$$

\section{RESULT}

\section{Panel Regression}

Panel data regression analysis is a regression analysis with the data structure which is panel data. Panel data is a combination of cross section data with time series data (Widarjono, 2013)states that there are several methods commonly used in estimating regression models with panel data, namely pooling least square (Common Effect), fixed effects approach (Fixed

\begin{tabular}{|c|c|c|c|c|c|c|}
\hline \multirow{2}{*}{ Variable } & \multicolumn{2}{|c|}{ Common Effect } & \multicolumn{2}{|c|}{ Fixed Effect ${ }^{* *}$ ) } & \multicolumn{2}{|c|}{ Random Effect } \\
\hline & Coeff. & Prob. & Coeff. & Prob. & Coeff. & Prob. \\
\hline EVA & -0.017772 & 0.4051 & 0.004673 & 0.9162 & -0.017772 & 0.3660 \\
\hline MVA & 0.097435 & $\left.0.0034^{*}\right)$ & 0.384850 & $\left.0.0000^{*}\right)$ & 0.097435 & $\left.0.0016^{*}\right)$ \\
\hline REVA & -0.023324 & 0.3072 & -0.050240 & 0.2305 & -0.023324 & 0.2676 \\
\hline $\mathrm{C}$ & -2.045189 & 0.0403 & -11.02326 & 0.0014 & -2.045189 & 0.0264 \\
\hline R-squared & \multicolumn{2}{|c|}{0.153769} & \multicolumn{2}{|c|}{0.411057} & \multicolumn{2}{|c|}{0.153769} \\
\hline Adj R-squared & \multicolumn{2}{|c|}{0.108435} & \multicolumn{2}{|c|}{0.244617} & \multicolumn{2}{|c|}{0.108435} \\
\hline F-statistic & \multicolumn{2}{|c|}{3.391917} & \multicolumn{2}{|c|}{2.469697} & \multicolumn{2}{|c|}{3.391917} \\
\hline Prob (F-statistik) & \multicolumn{2}{|c|}{0.024070} & \multicolumn{2}{|c|}{0.012183} & \multicolumn{2}{|c|}{0.024070} \\
\hline Durbin-Watson stat & \multicolumn{2}{|c|}{1.981144} & \multicolumn{2}{|c|}{1.972693} & \multicolumn{2}{|c|}{1.981144} \\
\hline
\end{tabular}
Effect), random effects approach (Random Effect).

Table 2. Equation Modelling 1 
Derivative Analysis of Value Added to Stock Returns at Jakarta Islamic Index

Table 3. Equation Modelling 2

\begin{tabular}{|c|c|c|c|c|c|c|}
\hline \multirow{2}{*}{ Variable } & \multicolumn{2}{|c|}{ Common Effect } & \multicolumn{2}{|c|}{ Fixed Effect } & \multicolumn{2}{|c|}{ Random Effect ${ }^{* *}$ ) } \\
\hline & Coeff. & Prob. & Coeff. & Prob. & Coeff. & Prob. \\
\hline EVA & -0.042698 & 0.5941 & 0.009826 & 0.6805 & 0.010298 & 0.6631 \\
\hline MVA & 0.680330 & $\left.0.0000^{*}\right)$ & 0.831813 & $\left.0.0000^{*}\right)$ & 0.830618 & $0.0000 *)$ \\
\hline REVA & 0.167833 & 0.0521 & -0.024215 & 0.2704 & -0.022626 & 0.2995 \\
\hline $\mathrm{C}$ & -16.39380 & 0.0000 & -17.40194 & 0.0000 & -17.42280 & 0.0000 \\
\hline R-squared & \multicolumn{2}{|c|}{0.453812} & \multicolumn{2}{|c|}{0.991739} & \multicolumn{2}{|c|}{0.866820} \\
\hline Adj R-squared & \multicolumn{2}{|c|}{0.426502} & \multicolumn{2}{|c|}{0.989591} & \multicolumn{2}{|c|}{0.860161} \\
\hline F-statistic & \multicolumn{2}{|c|}{16.61741} & \multicolumn{2}{|c|}{461.7492} & \multicolumn{2}{|c|}{130.1723} \\
\hline Prob (F-statistik) & \multicolumn{2}{|c|}{0.000000} & \multicolumn{2}{|c|}{0.000000} & \multicolumn{2}{|c|}{0.000000} \\
\hline Durbin-Watson stat & \multicolumn{2}{|c|}{0.065449} & \multicolumn{2}{|c|}{1.029829} & \multicolumn{2}{|c|}{0.887779} \\
\hline
\end{tabular}

Table 4. Equation Modelling 3

\begin{tabular}{|c|c|c|c|c|c|c|}
\hline \multirow{2}{*}{ Variable } & \multicolumn{2}{|c|}{ Common Effect } & \multicolumn{2}{|c|}{ Fixed Effect $* *$ ) } & \multicolumn{2}{|c|}{ Random Effect } \\
\hline & Coeff. & Prob. & Coeff. & Prob. & Coeff. & Prob. \\
\hline EVA & -0.017622 & 0.4141 & 0.006695 & 0.8758 & -0.017622 & 0.3536 \\
\hline MVA & 0.094697 & $0.0229 *)$ & -0.072225 & 0.7548 & 0.094697 & $0.0102 *)$ \\
\hline REVA & -0.024013 & 0.3144 & -0.034676 & 0.3967 & -0.024013 & 0.2534 \\
\hline Stock Price & 0.004026 & 0.9115 & 0.570225 & $\left.0.0396^{*}\right)$ & 0.004026 & 0.8994 \\
\hline $\mathrm{C}$ & -1.978222 & 0.0914 & -1.869996 & 0.7274 & -1.978222 & 0.0558 \\
\hline R-squared & \multicolumn{2}{|c|}{0.153960} & \multicolumn{2}{|c|}{0.464520} & \multicolumn{2}{|c|}{0.153960} \\
\hline Adj R-squared & \multicolumn{2}{|c|}{0.092430} & \multicolumn{2}{|c|}{0.297926} & \multicolumn{2}{|c|}{0.092430} \\
\hline F-statistic & \multicolumn{2}{|c|}{2.502194} & \multicolumn{2}{|c|}{2.788336} & \multicolumn{2}{|c|}{2.502194} \\
\hline Prob (F-statistik) & \multicolumn{2}{|c|}{2.502194} & \multicolumn{2}{|c|}{0.004622} & \multicolumn{2}{|c|}{0.052732} \\
\hline Durbin-Watson stat & \multicolumn{2}{|c|}{1.978843} & \multicolumn{2}{|c|}{2.119587} & \multicolumn{2}{|c|}{1.978843} \\
\hline
\end{tabular}

Information

$\begin{array}{ll}* \text { *) } & \text { Significance at level 0,05 } \\ * *) & \text { Model Chosen by Chow dan Haussman Test }\end{array}$

\section{Classical Assumption \\ Normality}

Normality test is a test that is carried out with the aim of assessing the distribution of data in a group of data or variables, whether the data distribution is normally distributed or not. This can be seen from the value of Jarque Berra, if the value is above 0.05 , the data is normally distributed.

Table 5. Normality Test

\begin{tabular}{lccc}
\hline & Equation 1 & Equation 2 & Equation3 \\
\hline Mean & $3.70 \mathrm{e}-18$ & 0.004718 & $-7.40 \mathrm{e}-18$ \\
Median & -0.009034 & 0.239033 & -0.034225 \\
Maximum & 0.430207 & 1.268340 & 0.362990 \\
Minimum & -0.322229 & -1.479208 & -0.358875 \\
Std. Dev. & 0.179074 & 0.853449 & 0.170752 \\
Skewness & 0.340709 & -0.380778 & 0.092881 \\
Kurtosis & 2.532318 & 1.743778 & 2.539901 \\
Jarque-Bera & 1.707644 & 5.754826 & 0.615497 \\
Probability & $\left.0.425785^{*}\right)$ & $\left.0.056280^{*}\right)$ & $0.735100^{*}$ ) \\
\hline
\end{tabular}

At table 5 , the test in equations 1,2 and 3 shows the jarque-berra probability value above 0.05 , it can be concluded that the data residuals are normally distributed.

\section{Autocorrelation}

The autocorrelation test is a statistical analysis conducted to determine whether there is a correlation between the variables in the prediction model and changes in time. Therefore, if the assumption of 
autocorrelation occurs in a prediction model, the disturbance value is no longer paired independently, but is paired in autocorrelation. This can be seen through the value of the durbin watson.

Table 6. Autocorrelation Test

\begin{tabular}{ccccccc}
\hline & $\begin{array}{c}\text { Durbin } \\
\text { Watson }\end{array}$ & dL & dU & 4-dU & 4-dL & Conclusion \\
\hline Equation 1 & 1.972693 & 1.4797 & 1.6889 & 2.3111 & 2.5203 & $\left.d U<d<4-d U^{*}\right)$ \\
Equation 2 & 0.887779 & 1.4990 & 1.6946 & 2.3054 & 2.501 & $0<d<d L$ \\
Equation 3 & 2.119587 & 1.4797 & 1.6889 & 2.3111 & 2.5203 & $\left.d U<d<4-d U^{*}\right)$ \\
\hline
\end{tabular}

From the table above, in the equation test 1 and 3, the Durbin Watson (DW) stat value is 1.972693 and is in the $\mathrm{dU}<\mathrm{d}<4-\mathrm{dU}$ interval, so it is concluded that there are no autocorrelation symptoms or problems. Except for equation 2, the value of Durbin Watson (DW) Stat is at the level of $0<\mathrm{d}$ $<\mathrm{dL}$, so the model experiences auticorrelation so it needs retesting with the non-parametric run test.

Table 7. Run Test

\begin{tabular}{lc}
\hline & Unstandardized Residual \\
\hline Test Value $^{\mathrm{a}}$ & $1268340,00^{\mathrm{b}}$ \\
Cases $<$ Test Value & 63 \\
Cases $>=$ Test Value & 1 \\
Total Cases & 64 \\
Number of Runs & 3 \\
Z &, 180 \\
Asymp. Sig. (2-tailed) &, $\left.857^{*}\right)$ \\
\hline
\end{tabular}

Based on the SPSS output above, the Asymp value is obtained. Sig. (2tailed) of $0.857>0.05$, it can be concluded that there are no autocorrelation symptoms or problems.

\section{Multicolinearity}

The multicollinearity test is a test that is carried out to ascertain whether in a regression model there is intercorrelation or collinearity between independent variables. Intercorrelation is a linear relationship or a strong relationship between one independent variable or predictor variable and other predictor variables in a regression model. The intercorrelation can be seen by the value of the correlation coefficient between the independent variables.

Table 8. Multicolinearity Test (Correlation)

\begin{tabular}{ccccc}
\hline & EVA & MVA & REVA & STOCK_PRICE \\
\hline EVA & 1.000000 & 0.305793 & 0.566056 & 0.262394 \\
MVA & 0.305793 & 1.000000 & 0.307825 & 0.650949 \\
REVA & 0.566056 & 0.307825 & 1.000000 & 0.393563 \\
STOCK_PRICE & 0.262394 & 0.650949 & 0.393563 & 1.000000 \\
\hline
\end{tabular}

Based on table 8 above, the correlation value of each independent variable is $<0.85$, it can be concluded that there is no multicollinearity problem.

\section{Heteroscedasticity}

The heteroscedasticity test is used to determine whether or not there are deviations from the classic assumption of heteroscedasticity, namely the inequality of variants of the residuals for all observations in the regression model. The prerequisite that must be met in the regression model is the 
absence of heteroscedasticity symptoms. There are several testing methods that can be used including the Park Test, the Glesjer Test.

Table 9. Heteroscedasticity Test (Glejser)

\begin{tabular}{ccccccc}
\hline Variable & \multicolumn{2}{c}{ Equation 1 } & \multicolumn{2}{c}{ Equation 2 } & \multicolumn{2}{c}{ Equation 3 } \\
& Coeff. & Prob. & Coeff. & Prob. & Coeff. & Prob. \\
\hline EVA & 0.015584 & $0.5087^{*}$ ) & 0.011557 & $\left.0.5991^{*}\right)$ & 0.028997 & $\left.0.1941^{*}\right)$ \\
MVA & -0.022180 & $\left.0.6149^{*}\right)$ & -0.024325 & $\left.0.5439^{*}\right)$ & -0.116527 & $\left.0.3317^{*}\right)$ \\
REVA & -0.000432 & $0.9844^{*}$ ) & -0.029210 & $0.1594^{*}$ ) & -0.000417 & $0.9842^{*}$ ) \\
Stock Price & - & - & - & - & 0.188579 & $\left.0.1816^{*}\right)$ \\
C & 0.472908 & 0.7843 & 1.997265 & 0.1847 & 1.506138 & 0.5871 \\
\hline
\end{tabular}

At table 9, the test in equations 1,2 and 3 obtains a probability value greater than 0.05 , it can be concluded that there is no heteroscedasticity problem.

\section{DISCUSSION}

\section{The Effect of Economic Value Added (EVA) on Stock Prices}

Based on the results of the research conducted, it is stated that EVA does not have a significant effect on stock prices. This is indicated by a probability value of $0.6631>0.05$ and $\beta$ of 0.010298 , so it cannot prove the research hypothesis in which there is an effect of stock prices calculated from the current year's closing price with economic value added.

This means that the ups and downs of stock prices do not affect EVA. Because the above results can be related to the complexity in calculating EVA, which is not directly available in the financial statements so that it requires a lot of data. Therefore, capital market players experience time constraints in making investment decisions if they must first calculate EVA. According to Mahbub \& Oetomo (2007), this happens because the concept of EVA has not been considered by investors in investing in stocks in Indonesia. It can also be said that the determinants of investing in stocks have not used EVA as a measure of the company's financial performance. The results of this study support the research of Agnatia and Amalia, Mardiyanto which state that EVA does not have a significant effect on stock prices (Agnatia \& Amalia, 2018; Mardiyanto, 2013).

\section{The Effect of MarketValue Added (MVA) on Stock Prices}

Based on the results of research conducted, it states that MVA has a significant positive effect on stock prices. This is indicated by the probability value of $0.0000<0.05$ and $\beta$ of 0.830618 , so that it can prove the research hypothesis in which there is an effect of stock prices with market value added.

This means that the size of the share price is influenced by the MVA value. This shows that MVA is able to create value for shareholders. According to Sonia et al. (2014), for companies that the positive value of MVA reflects the size of the company's investment projects estimated by the capital market, both those that have occurred and those that will occur in the future. MVA shows the cumulative results of the company's performance generated by various investments that have occurred or will occur. Investors 
need to understand the company's performance that is able to generate added value for the shares invested. The results of this study support the previous research which state that MVA has a significant positive effect on stock prices (Mardiyanto, 2013; Nugroho, 2018; Sonia et al., 2014).

\section{The Effect of Refined Economic Value Added (REVA) on Stock Prices}

Based on the results of the research conducted, it was stated that REVA had no significant effect on stock prices. This is indicated by the probability value of $0.2995>0.05$ and $\beta$ of -0.022626 , so that it cannot prove the research hypothesis in which there is an effect of stock prices with refined economic value added.

This means that the ups and downs of stock prices do not affect the REVA value. If the company has the ability to meet the company's obligations and provide profits to investors through dividend distribution, it will not affect the rise and fall of share prices in the market. Shifts in share prices can be caused by a company's positive or negative sentiment from the market. The results of this study support the previous research, which states that refined economic value added does not have a significant effect on stock prices (Febriyanto \& Rizkiyanto, 2015; Silaban, 2013).

\section{The Effect of Economic Value Added (REVA) on Return Stock}

Based on the results of the research conducted, it states that EVA does not have a significant effect on stock returns. This is indicated by the probability value of $0.9162>0.05$ and $\beta$ of 0.004673 , so that it cannot prove the research hypothesis in which there is an effect of stock returns calculated from the difference between the closing price of the previous year and the current year with economic value added.

This shows that the company is unable to create added economic value for the company and its shareholders. So that the company cannot fulfill the company's obligations and meet investors' expectations. According to Sunardi (2010), this occurs due to the lack of knowledge of investors in Indonesia regarding the benefits and calculations of Economic Value Added in making investment decisions. The results of this study support the previous research, which states that EVA has no effect on stock returns (Kusuma \& Topowijono, 2018; Sunardi, 2010).

\section{The Effect of Market Value Added (REVA) on Return Stock}

Based on the results of the research conducted, it states that MVA has a significant positive effect on stock returns. This is indicated by the probability value of $0.0000<0.05$ and $\beta$ of 0.384850 , so that it can prove the research hypothesis in which there is an effect of stock returns on market value added.

Based on the results of this study, the positive value of the MVA coefficient indicates that added value for the company and wealth for shareholders has been successfully created by the company so that the company's performance gets a large response from the market. Thus, investor confidence in the company is increasing and demand for shares 
increases. High demand causes high share prices, so that capital gains will also increase because when the price rises, shareholders can sell them back. As capital gains increase, stock returns will also increase because it is a component of the stock return calculation. The results of this study support the previous research, which state that MVA has a significant positive effect on stock returns (Alexander \& Destriana, 2013; Kusuma \& Topowijono, 2018; Nugroho, 2018).

\section{The Effect of Refined Economic Value Added (REVA) on Return Stock}

Based on the results of the research conducted, it states that REVA does not have a significant effect on stock returns. This is indicated by a probability value of $0.2305>0.05$ and $\beta$ of -0.050240 , so that it cannot prove the research hypothesis in which there is an effect of stock returns with refined economic value added.

The results of this study are in line with the research of Lestari \& Oktaria (2019) which states that REVA has no effect on stock returns. According to Lestari \& Oktaria (2019), the stock returns obtained are not reflected in the performance of the companies owned by the sample companies. This is due to the company's treatment and investor judgment in combining business decisions in the capital market, as well as management decision making in maximizing profit and the company's operational management is also affected by differences in characteristics in each industrial sector.

\section{Effect of Stock Prices as Mediation of EVA, MVA and REVA on Stock Return}

Based on the results of research conducted, it states that stock prices have a significant positive effect on stock returns. This is indicated by the probability value of $0.0396<0.05$ and $\beta$ of 0.570225 , so that there is an effect of stock prices on stock returns.

This shows that the higher the stock price, the higher the stock returns of the sample companies. The results of this study are in line with Setiyanti (2016)research which states that stock prices have a significant effect on stock returns. Based on the results of research conducted, it states that stock prices have a significant positive effect on stock returns. This is indicated by the probability value of $0.0396<0.05$ and $\beta$ of 0.570225 , so that there is an effect of stock prices on stock returns.

Based on the sobel criteria, the stock price is only able to mediate MVA on stock returns. The mediating variable (stock price) is stated as a partial mediation variable because the MVA has a direct or indirect effect on stock returns through stock prices. Meanwhile, if the MVA has no direct effect on stock returns (only has a significant effect on stock prices), while stock prices have a significant effect on stock returns, it is perfect mediation.

\section{CONCLUSION}

Economic value added (EVA) has no effect either on stock prices or stock returns, market value added (MVA) affects the stock price and stock return, refined economic value added (REVA) has no effect on both. Based on the sobel criteria, the stock price is only able to mediate MVA on stock returns. The mediating variable (stock price) is stated as a partial mediation variable because the 
MVA has a direct or indirect effect on stock returns through stock prices. Meanwhile, if the MVA has no direct effect on stock returns (only has a significant effect on stock prices), while stock prices have a significant effect on stock returns, it is perfect mediation.

\section{BIBLIOGRAPHY}

Agnatia, V., \& Amalia, D. (2018). Pengaruh Economic Value Added EVA dan Rasio Profitabilitas Terhadap Harga Saham. Journal of Applied Managerial Accounting, 2(2), 290-303. https://doi.org/10.30871/jama.v2i2.900

Alexander, N., \& Destriana, N. (2013). Pengaruh Kinerjad Keuangan Terhadap Return Saham. In Jurnal Bisnis dan Akuntansi (Vol. 15, Issue 2). https://doi.org/10.34208/JBA.V15I2.124

Andrias, S. S., \& Margasari, N. (2017). Pengaruh Economic Value Added (EVA) dan Market Value Added (MVA) terhadap Return Saham pada Perusahaan Manufaktur yang Terdaftar Di BEI. Jurnal Manajemen Dan Bisnis Indonesia, 490-500.

Bacidore, J. M., Boquist, J. A., Milbourn, T. T., \& Thakor, A. V. (1997). The Search for the Best Financial Performance Measure. Financial Anaiysts Journai, may/june.

Baron, R. M., \& Kenny, D. A. (1986). The Moderator-Mediator Variable Distinction in Social Psychological Research: Conceptual, Strategic, and Statistical Considerations. 51(6), 1173-1182.

Bodie, Z., Kane, A., \& Alan J. Marcus. (2006). Investasi (6th ed.). Salemba Empat.

Cahyadi, H., \& Darmawan, A. (2016). Pengaruh Economic Value Added, Market Value Added, Residual Income, Earning dan Arus Kas Operasi terhadap Return Saham (Studi Empiris pada perusahaan LQ-45). Media Ekonomi, 16(1), 176-195. https://doi.org/10.30595/medek.V16I1.1144

Febriyanto, D., \& Rizkiyanto, E. (2015). Komparasi Pengaruh Economic Value Added (EVA) dengan Refined Economic Value Added (REVA) Terhadap Harga Saham dan Return Saham Perusahaan Terdaftar pada Sektor Manufaktur. FE, UI. http://lib.ui.ac.id/naskahringkas/2017-03/S58217Dony Febriyanto

Ferguson, R., \& Leistikow, D. (1998). Search for the best financial performance measure: Basics are better. Financial Analysts Journal, 54(1), 81-85. https://doi.org/10.2469/faj.v54.n1.2148

Haanurat, A. I. (2013). Pengaruh Karakteristik Perusahaan dan Ekonomi Makro terhadap Return Saham Syariah yang Listing di Jakarta Islamic Index / Haanurat / Jurnal Manajemen dan Bisnis. 3(2). http://jurnal.ubl.ac.id/index.php/jmb/article/view/598

Kusuma, R. A., \& Topowijono, T. (2018). Pengaruh Economic Value Added (EVA) dan Market Value Added (MVA) Terhadap Return Saham (Studi pada Perusahaan yang Terdaftar dalam Indeks LQ45 di Bursa Efek Indonesia Periode 2012-2016). Jurnal Administrasi Bisnis, 61(3), 65-72. 
Derivative Analysis of Value Added to Stock Returns at Jakarta Islamic Index

http://administrasibisnis.studentjournal.ub.ac.id/index.php/jab/article /view/2599

Lestari, A., \& Oktaria, H. (2019). Pengaruh Refined Economic Value Added terhadap Return Saham pada Perusahaan Nonkeuangan yang Terdaftar Di Bursa Efek Indonesia. Journal of Applied Managerial Accounting, 3(1), 107-115.

Mahbub, A., \& Oetomo, H. W. (2007). Analisis Kinerja Keuangan dengan Metode Economic Value Added dan Market Value Added Perusahaan Rokok. Jurnal Akuntansi, Manajemen Bisnis Dan Sektor Publik (JAMBSP), $4(1)$.

Mardiyanto, H. (2013). Analisis Pengaruh Nilai Tambah Ekomoni dan Nilai Tambah Pasar terhadap Harga Saham pada Perusahaan Sektor Ritel yang Listing di BEI. Jurnal Ilmu Manajemen (JIM), 1(1). https://jurnalmahasiswa.unesa.ac.id/index.php/jim/article/view/1515

Nugroho, M. (2018). The Effect of Economic Value Added (EVA), Market Value Added (MVA), Refined Economic Value Added (REVA) on Stock Prices and Returns Stock at Manufacturing Industries Who Listed on Indonesia Stock Exchange (BEI). Archives of Business Research, 6(12), 173-188.

Rahadjeng, E. R. (2019). Analisis Perbandingan Kinerja Perusahaan Otomotif dan Komponen yang Tercatat di Bursa Efek Indonesia dengan Menggunakan EVA, REVA, FVA dan MVA. BENEFIT Jurnal Manajemen $\begin{array}{lll}\text { Dan } \quad \text { Bisnis, } & \text { 102-110. }\end{array}$ https://doi.org/https://doi.org/10.23917/benefit.v4i1.7789

Rosmawati, R. (2018). Pengaruh Economic Value Added Terhadap Harga Saham Perusahaan Manufaktur Yang Terdaftar Di Bursa Efek Indonesia. Perspektif: Jurnal Pengembangan Sumber Daya Insani, 3(2), 377-381. https://doi.org/10.26618/Perspektif.V3I2.1670

Sartono, A. (2010). Manajemen Keuangan Teori dan Aplikasi (4th ed.). BPFE.

Setiyanti, S. W. (2016). Pengaruh Likuiditas Saham dan Harga Saham Terhadap Return Saham Perusahaan Investasi Komoditi Emas yang Terdaftar di Bursa Efek Jakarta (BEJ). Jurnal Mimbar Bumi Bengawan, 8(17).

asmisolo.ac.id/jurnal/index.php/jmbb/article/view/68

Silaban, S. N. (2013). Pengaruh Economic Value Added (EVA), Refined Economic Value Added (REVA), dan Market Value Added (MVA) secara bersama-sama maupun parsial terhadap Harga Saham pada sektor Industri Pertambangan di Bursa Efek Indonesia (BEI) periode 2007-2011. http://repository.widyatama.ac.id/xmlui/handle/123456789/8138

Sonia, B., Zahroh, \& Farah, D. (2014). Analisis Pengaruh Economic Value Added (EVA), Market Value Added (MVA) dan Return On Investment (ROI) terhadap Harga Saham (Studi pada Perusahaan Property dan Real Estate yang Terdaftar di Bursa Efek Indonesia Periode 2009-2012). Jurnal A, 9(1), 1-10.

Sugiyono. (2017a). Metode Penelitian Bisnis: Pendekatan Kuantitatif, 
Kualitatif, Kombinasi, R\&D (S. Y. Suryandari (ed.); 3rd ed.). CV Alfabeta. Sugiyono. (2017b). Metode Penelitian Bisnis (3rd ed.). Alfabeta.

Sunardi, H. (2010). Pengaruh Penilaian Kinerja dengan ROI dan EVA terhadap Return Saham pada Perusahaan yang Tergabung dalam Indeks LQ 45 di Bursa Efek Indonesia. In Jurnal Akuntansi (Vol. 2, Issue 1).

Syahputra, A. (2018). Analisis EVA, EPS dan PER terhadap Return Saham pada Perusahaan Sub Sektor Makanan \& Minuman (Periode Tahun 2016-2017). Jurnal Ilmiah Akuntansi Universitas Pamulang, 6(2), 174185.

Widarjono, A. (2013). Ekonometrika Teori dan Aplikasi. Ekonisia FE UII.

Young, S. D., \& O'Byrne, S. (2001). EVA and Value Based Management: A Practical Guide to Implementation. McGraw-Hill. https://www.researchgate.net/publication/260419449_EVA_and_Value _Based_Management_A_Practical_Guide_to_Implementation 